\title{
LANGUAGE LEARNING STRATEGIES AND SELF-REGULATION SKILLS OF UNIVERSITY PREPARATORY SCHOOL AND PRIVATE LANGUAGE COURSE STUDENTS $^{1}$
}

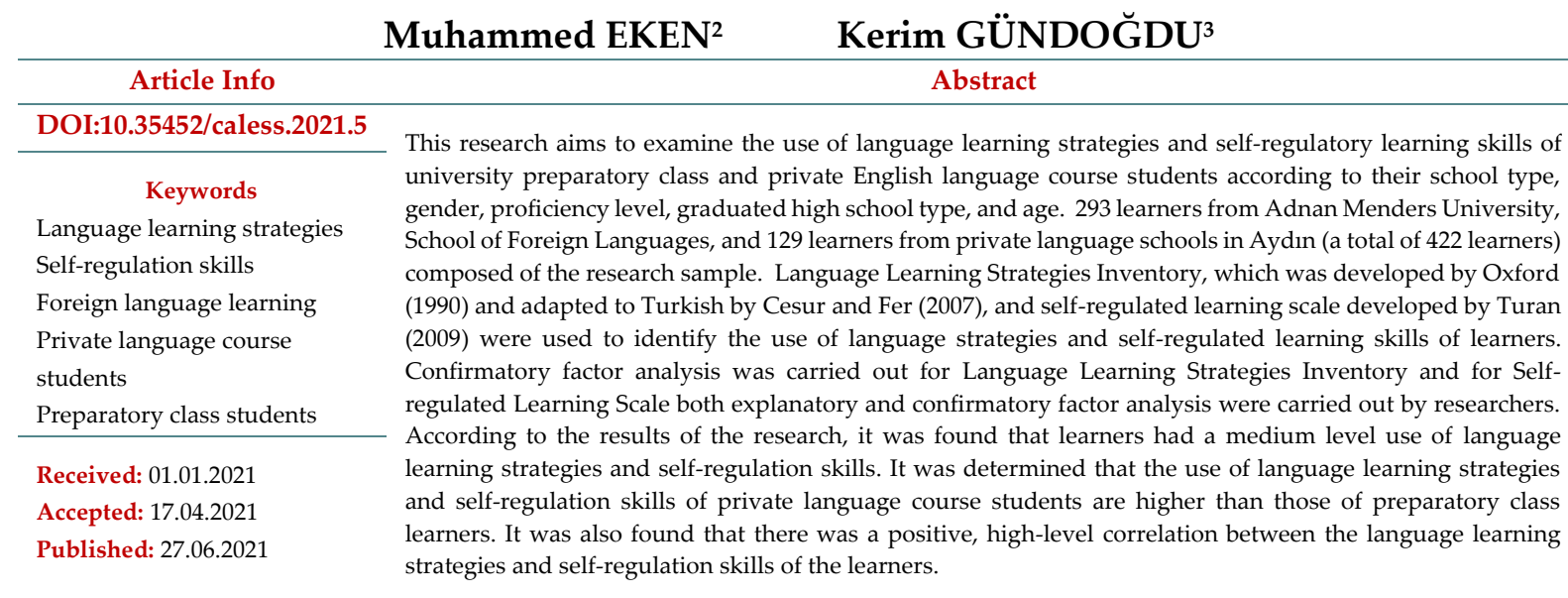

\section{ÜNIVERSITE HAZIRLIK SINIFI VE ÖZEL DİL KURSU ÖĞRENCILERININN YABANCI DİL ÖĞRENME STRATEJİLERI VE ÖZ DÜZENLEME BECERILLERİ}

\begin{tabular}{|c|c|}
\hline Makale Bilgisi & Özet \\
\hline DOI:10.35452/caless.2021.5 & \multirow{10}{*}{ 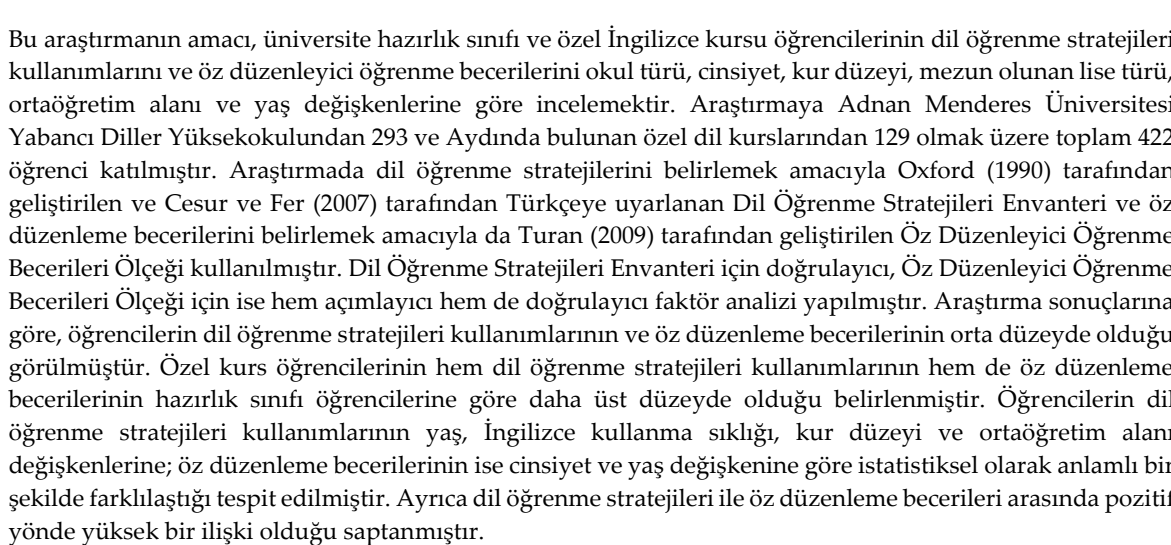 } \\
\hline Anahtar Kelimeler & \\
\hline Dil öğrenme stratejileri & \\
\hline Öz düzenleme becerileri & \\
\hline Yabancı dil öğrenimi & \\
\hline Yabancı dil kursu öğrencileri & \\
\hline Hazırlık sınıfı öğrencileri & \\
\hline Gönderim Tarihi: 01.01.2021 & \\
\hline Kabul Tarihi: 17.04.2021 & \\
\hline Yayın Tarihi: 27.06.2021 & \\
\hline
\end{tabular}

APA'ya göre alıntılama: Eken, M. ve Gündoğdu, K. (2021). Üniversite hazırlık sınıfı ve özel dil kursu öğrencilerinin yabancı dil öğrenme stratejileri ve öz düzenleme becerileri. Uluslararası Dil, Eğitim ve Sosyal Bilimlerde Güncel Yaklaşımlar Dergisi (CALESS), 3 (1), 83-114.

Cited as APA: Eken, M., \& Gündoğdu, K. (2021). Language learning strategies and self-regulation skills of university preparatory school and private language course students. International Journal of Current Approaches in Language, Education and Social Sciences (CALESS), 3 (1), 83-114.

\footnotetext{
${ }^{1}$ This study is a part of master thesis named Language Learning Strategies and Self-regulation Skills of University Preparatory School and Private Language Course Students.

2 (D) Aydın Adnan Menderes University, Turkey, muhammed.ekeen@gmail.com

3 (iD) Aydın Adnan Menderes University, Turkey, kerim.gundogdu@adu.edu.tr
} 


\section{Introduction}

Thanks to the rapidly advancing communication technologies, it has never been so easy to communicate with each other for people from different nations throughout history. Today, people can communicate with each other visually and audibly as well as by texting through smartphones or other similar devices. Despite this progress in communication, the talents, efforts, and experiences of individuals are still considered as important as before. Humans had tried to overcome handling lots of different languages to communicate by establishing a common language facilitating communication. These common tongues have often been the languages of the states that have retained the economic, military, or political power of the era; Latin, French and English (Jenkins, 2009).

The number of people using English as a common medium of communication in the world has been increasing, thus English is adopted as a significant language worldwide. (Seidlhofer, 2009). It has been used as a common language in fields such as communication, economics, and education even in countries where the official language is not English (Jerkins, 2009). English is spoken by about 600 million people whose native language is not English. Accordingly, it can be said that people prefer to use English frequently to communicate apart from their mother tongue (Lewis et al., 2016).

Individuals use their ways and strategies while learning languages. Some of these learners are more successful in learning foreign languages than others, and they have individual learning behaviours that are not in others (Oxford, 1990). In recent years, it has become evident that learning and acquiring a foreign language is getting more important in favour of developing technology and communication possibilities; consequently, it becomes a popular topic among researchers. Traditional studies were carried out in the context of a class environment in which students could gather for the same purpose and learn in the same way. From the 1970s onwards, learning behaviours, skills or strategies of a good language learner have begun to be revealed in the research (Chamot \& El-Dinary, 1999; Cohen, 2003; Naiman, Frohlich, Stern \& Todesco, 1978; Stern, 1975), and it has been emphasized on their cognitive learning processes, particularly how they have consciously or unconsciously dealt with and perceived their learning (O'Malley \& Chamot, 1990; Oxford, 1990; O'Malley, Chamot, Stewner, Kupper \& Russo, 1985). 
Along with many experimental studies with successful learners, the individual differences of learners towards the end of the 1980s have begun to be examined. These studies were based on the assumption that learners' characteristics, such as proficiency (Anderson, 1991; Bedell \& Oxford, 1996; Chamot \& El-Dinary, 1999), learning style (Ehrman \& Oxford, 1990; Reid, 1987), gender (Bacon, 1992; Ehrman \& Oxford, 1995), motivation (Cohen \& Dörnyei, 2002; Gardner, 1985; Oxford \& Nyikos, 1989), and anxiety (Horwitz, 1988; Horwitz \& Cope, 1986), directly or indirectly affected learning language. As a result, the use of strategy in learning foreign languages and the responsibilities of learners in their learning have become more prominent than in the past.

As seen in these studies, the knowledge, skills, and experiences that students have gained in their endeavour have a long-lasting impact on their foreign language learning. Rubin (1975) pointed out that the strategies used by successful foreign language learners need to be examined in detail and emphasized that teachers need to teach strategies that are already more useful to students who do not use or use less of these strategies. Learning environments in which the teacher is the absolute power in traditional education give its way to learning environments where students behave much more actively. In this context, the role of the teacher changes to a facilitator or guide rather than a source of knowledge in the classroom with the developing technology and education technology. It is remarkably possible that the three aspects of language proficiency, language learning skills, and an underlying value for learning the language could be the key to autonomous language learning: that being a situation where learners like what they do, get in control of their learning and take steps to achieve or regulate the cases they try to learn (Nakata 2010). In this meaning, concepts such as 'learning to learn', 'autonomous learning' and 'self-regulation' have emerged.

\subsection{Self-regulation}

Self-regulation is a concept that has emerged as a reason for the differences in the learning processes of students, especially in terms of time and productivity (Zimmerman, 2002). Regarding Zimmerman's model of self-regulation, we can think of particular stages of self-regulation (Zimmerman, 2002). In the first stage, the forethought phase, learners analyse the task and set their objectives. On this basis, they arrange which strategies to need to achieve these objectives. All process is influenced by motivation of learners. Moreover, this covers their present motivational state concerning the particular task as well as their remaining motivational manners like their perceived self-efficacy or goal orientations. Students with self-regulatory skills 
are aware of the responsibility for their learning, and they also know that they have the primary liability of their learning or education.

Pintrich (2000) defines self-regulation as an effective and constructive process in which learners set their learning goals, manipulate their motivation, behaviours, and cognition, and it is guided, constrained, and guided by goals and environments. Pintrich's model is mostly attracted to the components of motivation and target orientation of the self-regulation process. There are four stages in Pintrich's selfregulation model (2000) which is defined by the interaction of cognitive, motivational, sensory and biological individual processes and behavioural and contextual processes. The first stage consists of forecasting, planning, and activation, the second stage includes tracking, then the third stage control, and the final stage includes response and reflection. Meanwhile, they organize the preparations, time, and environment for their learning efficiently and try to overcome the difficulties they face in this direction by getting help from their environment (Çelik, 2012). Senemoğlu (2010) affirmed that in compliance with Bandura's social-cognitive theory, individuals could evaluate their behaviours by observing and comparing them with their criteria, and they could regulate their behaviour by reinforcing or punishing themselves.

\subsection{Language learning skills}

Research into language learning strategies has passed through several phases since the first studies of good language learners nearly four decades ago (Pawlak, 2019). Oxford (1990) suggested an expanded definition of strategies as 'specific actions taken by the learner to make learning easier, faster, more enjoyable, and more self-directed and more transferable to new situations (Oxford, 1990, p. 8). Various models have been suggested so far for the categorization of language learning strategies depend on their use and role in the learning process. According to Oxford (1990), it is not convincing yet how many strategies are possible, how they ought to be described and classified, and whether it will be possible to establish a certain and validated hierarchy of strategies. More, it is not possible to come to an eventual agreement on precisely among the theorists. But still, some major models have emerged in the field so far which are Rubin's classification of direct and indirect strategies, Oxford's six-category model (SILL), O'Malley and Chamot's four-category strategy taxonomy (Ayhan, 2016).

When language learners apply strategies that are more appropriate for them, it is revealed that they are to have a more permanent and easy learning process (El-Dip, 2004; Oxford, 2003; Wherton, 2000). Thus, instead of just teaching the language directly 
to the learners, teaching both the target language and the language learning strategies, and regarding them as responsible for their learning may lead to better language acquisition. Teachers should provide an environment and opportunity for students to develop an effective language learning strategy in the classroom environment since language learning strategies and beliefs are considered to be crucial factors for learning a foreign language (Dickinson, 1995, Wenden, 1991). To do this, it is necessary to determine the language learning strategies and levels of the students primarily.

Many of the studies have found a relationship between strategy teaching and language achievement (Baş, 2014; Carrell, 1998, Chamot, 1993, O'Malley \& Chamot, 1990, Oxford, 1990). Teachers can also help students to learn how, where, and when to use these strategies as they learn the language by incorporating strategy teaching into their English language programs. The studies on foreign language learning strategies are mostly limited to high school and university students (Akın, 2001, Rao, 2016, Tang \& Tian, 2015; Wherton, 2000).

\subsection{The current study}

As mentioned above, the importance of language learning strategies and selfregulatory skills are highly important while learning a foreign language. Learning a foreign language should not be only seen just as a formal course that can be taught in formal education same as some other courses. Learners should control and organize themselves, moreover, build their language learning strategies according to their outcomes in this process. As a result of the findings of this research, teachers can organize teaching environments and plan activities according to strategies that are used extensively by students, and also support them regarding less preferred strategies. Besides, the gathered data can be shared with the policymakers planning the content and curriculum on behalf of a more learner-centred language learning.

Çetinel (2009) stated that according to Dündar Uçar, Chairman of the Wall Street Institute Turkey, nearly between twenty-five and thirty thousand people enrolled on foreign language teaching courses and paid approximately fifty million Turkish Liras every year. According to these numbers, it is considered important to determine the foreign language learning strategies of students not only in the official institutions but also in other language teaching institutions. The related literature shows that no study examines the private language course learners' language learning strategies and selfregulatory skills in Turkey. Thus, we decided to study with this group and to compare their strategy use and self-regulation skills with a similar group of preparatory class 
students since they have a similar kind of learning and teaching curriculum based on the Common European Framework of References.

The current research aims to examine the language learning strategy use and selfregulatory skills of the learners focusing on their foreign language learning strategies and self-regulation skills of the students who attend public university-preparatory class (public) and private language learning course (private). In this direction, the following sub-problems are tried to be revealed in this research.

1. What are the language learning strategies and self-regulation skills of university preparatory class and private language course students?

2. Do language learning strategies and self-regulation skills of preparatory class and private language course students differ according to the type of school, gender, type of secondary school, proficiency levels, and frequency of using English?

3. Is there a significant relationship between language learning strategies and selfregulation skills?

\section{Methodology}

Creswell (2013) stated that the research model should be determined before starting the study to guide how data are collected and interpreted. General survey models are a scan of the entire population or selected sample or sample to reach a general judgment about a large universe (Creswell, 2013; Karasar, 2014; Punch, 2013). In this research, relational survey model was used to determine foreign language learning strategies and self-regulation skills of university preparatory class and private language course students. The relational survey models were defined as a research model that aims to determine the presence and/or degree of coexistence between two or more variables (Büyüköztürk et al., 2014; Karasar, 2014; Kothari, 2004).

\subsection{Participants}

The population of the study consisted of 458 students attending the preparatory class of Adnan Menderes University School of Foreign Languages and 248 students attending language courses. The study was attempted to reach the entire population without using any sampling methods as it was called study population or accessible population by Karasar (2014). And 293 preparatory class students and 129 language course students joined the study voluntarily after eliminating the invalid and unappropriated answers. Participants' ages range mostly between 18 and 24 years, so it can be said they are in a similar lifetime period. Cohen et al. (2000) have calculated 
the theoretical sample sizes where the population is known and stated that 278 people were sufficient for a \%95 confidence interval in the population of 1000 people (as cited in Erkuş, 2005), thus it was accepted that the number of participants was enough for the study.

Table 1. Personal information of the participants

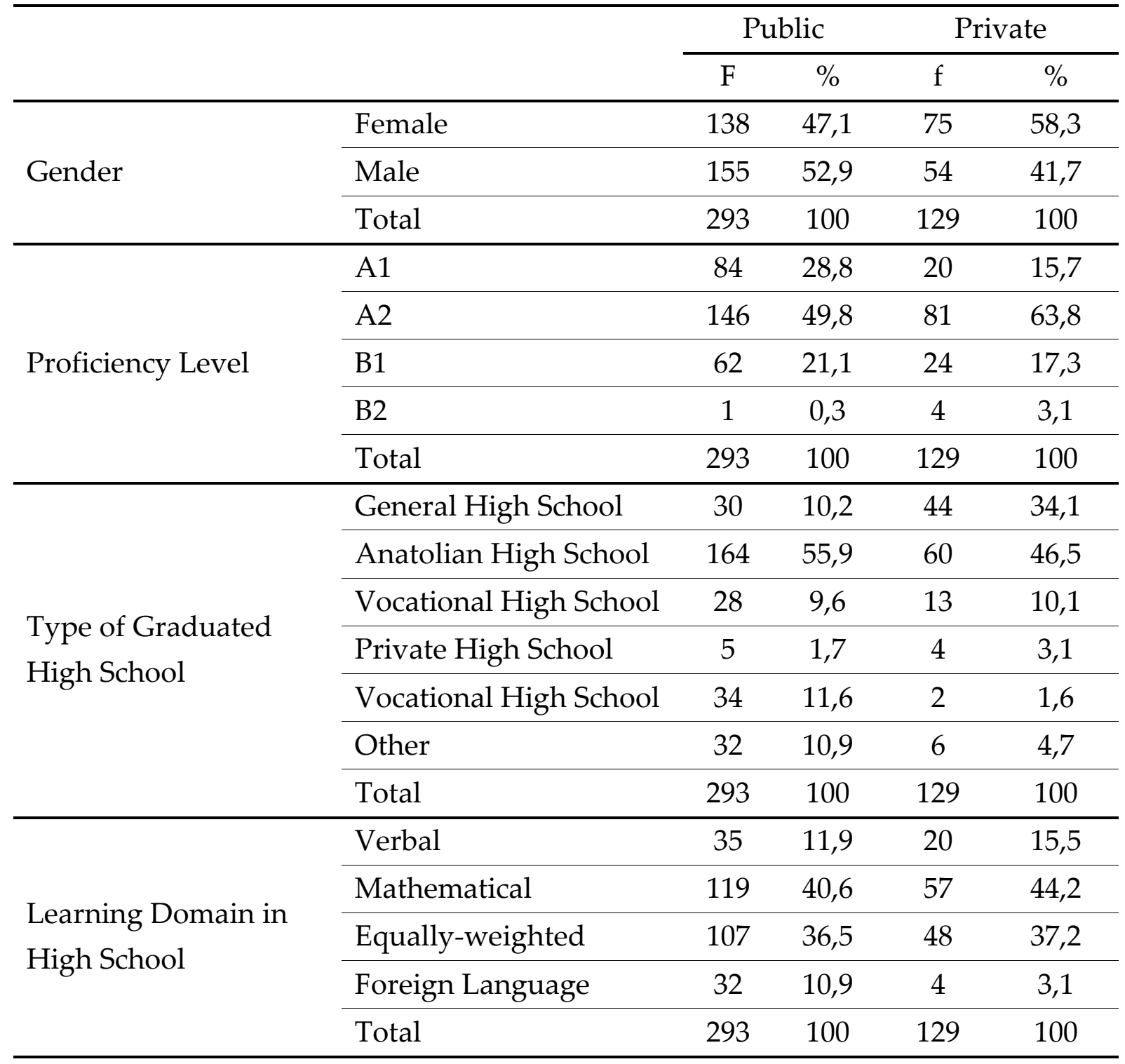

\subsection{Data Collection Instruments}

\subsubsection{Strategy inventory for language learning (SILL)}

To investigate the level of language learning strategies of the participants, Oxford's (1990) SILL which was adapted to Turkish by Cesur and Fer (2007) was used. Inventory consists of 50 items and there are two main categories named direct and indirect strategies. Also, each of these categories is further divided into three subcategories. Direct strategies consist of memory, cognitive and compensation strategies, 
while indirect strategies consist of metacognitive, affective, and social strategies. Oxford (1990) states that there are three references points as high, medium, and low. Scores that are below 2.4 considered to be "low", scores between 2.5 and 3.4 considered to be "medium" and scores between 3.5 and 5 are thought to be "high".

To validate the scale, principal component analysis was performed by Cesur and Fer (2007). As a result of the analysis, Kaiser-Meyer-Olkin (KMO) value was found to be 93. The communality variance of the inventory was found to be between .39 and .66. It was determined that the inventory was collected in 6 dimensions with an eigenvalue greater than 1 and $42 \%$ of the total variance was explained. The internal consistency reliability coefficient of the whole inventory was found as .92. For the validity analysis of the instrument, Confirmatory Factor Analysis (CFA) was conducted by using Lisrel 8. Confirmatory factor analysis was performed in the same sample of 422 prep classes and private language course students. Practices of confirmatory factor analysis in the same sample do not pose any problems (Jöreskog \& Sörbom, 1993; Thompson, 2005, as cited in Özdemir et al.). According to the results of confirmatory factor analysis, it was confirmed that the inventory has a 6-dimensional structure ( $\mathrm{df}=1160$, Chi-square 3082,071, RMSEA=0,062, GFI=0,838, AGFI=0,821, CFI=0,956).

\subsubsection{Self-regulated learning skills scale}

To investigate the level of self-regulated learning skills of the participants Turan's (2009) Self-regulated learning skills scale was used. The scale consists of 41 five point Likert- type items and four dimensions respectively; motivation and action for learning, planning and goal setting, strategy use and evaluation, and addiction in learning.

This 41-item scale developed by Turan (2009) was used as a data collection tool in the research. However, the fit indices of the scale were found low after applying the confirmatory factor analysis. Thus, principal component analysis was performed by the researchers and items with a factor load of less than .40 and with a factor difference of more than one factor less than .10 were excluded from the scale until forming the appropriate structure. As a result, a scale that consists of 16 items and 3 dimensions was formed. Although the first three dimensions of the scale, motivation and action, planning and goal setting, and strategy use remains, the dimension of addition in learning was removed. And the remaining items located in three dimensions respectively; 1 to 7 in strategy use and evaluation $(\alpha=.81), 8$ to 12 in planning and goal setting ( $\alpha=.79)$, and 13 to 16 in motivation and action for learning ( $\alpha=.71)$. The factor 
loadings of these 16 items are between .54 and .80 and explain $52.31 \%$ of the total variance $(\alpha=.88)$. For the validity analysis of the instrument, Confirmatory Factor Analysis (CFA) was conducted by using Lisrel 8. According to the results of confirmatory factor analysis, it was confirmed that the inventory has a 3-dimensional structure ( $\mathrm{df}=101$, Chi-square=256,720, RMSEA=0,054, GFI= 0,931，AGFI=0,907, CFI $=0,972$ ).

\subsection{Gathering and Analyzing the Data}

In the research, the data were gathered in the second term of the 2015-2016 academic year, since it was expected students got a certain level of education in their institutions. Both institutions have adopted the Common European Framework of References (CEFR) proficiency level system. Students who just try to achieve and to get a certain point in the Foreign Language Exam instead of CEFR were not included in the present study. The scales were distributed and explained to the participants by the researchers. The scales were applied simultaneously to both preparatory class and language course students in their institutions before or after their courses. It took 15-20 minutes to complete both scales together. The data obtained at the end of the application were coded and transferred to the SPSS 20.0 package program to perform the proper statistical analyzes. To test the normality of the research data, the Shapiro-Wilk normality test was applied. Accordingly, it was observed that all variables were normally distributed for both language learning strategies and self-regulation skills ( $p>05)$. Besides, when the kurtosis and skewness coefficients of the variables were examined, it was seen that all values were between -1.5 and +1.5 , so it was assumed the data were distributed normally. (Tabachnick \& Fidell, 2013). Therefore, parametric tests were used while analysing the data. Considering the research problem and sub problems frequency, independent sample t-test, Pearson correlation analysis and oneway ANOVA analysis were performed. 


\section{Results}

\subsection{Level of Language Learning Strategies and Self-Regulated Learning Skills of} Participants

Table 2. Level of language learning strategies of participants

\begin{tabular}{lllll}
\hline \multirow{2}{*}{ Memory Strategies } & & $\mathbf{N}$ & $\overline{\mathbf{x}}$ & SD \\
& Public & 289 & 2.99 & .81 \\
& Private & 124 & 3.47 & .71 \\
\hline \multirow{2}{*}{ Cognitive Strategies } & Public & 289 & 2.87 & .81 \\
& Private & 124 & 3.29 & .68 \\
\hline \multirow{2}{*}{ Meta Cognitive Strategies } & Public & 289 & 3.07 & .78 \\
& Private & 124 & 3.18 & .69 \\
\hline \multirow{2}{*}{ Affective Strategies } & Public & 289 & 3.19 & .87 \\
& Private & 124 & 3.51 & .74 \\
\hline \multirow{2}{*}{ Social Strategies } & Public & 289 & 2.84 & .79 \\
& Private & 124 & 3.06 & .75 \\
\hline \multirow{2}{*}{ Mean } & Public & 289 & 3.11 & .77 \\
& Private & 124 & 3.31 & .68 \\
\hline
\end{tabular}

As seen in Table 2 above, it is seen that the average use of general strategy of public students is 3.00 and the general strategy usage average of private language course students is 3.33. In the averages obtained from the answers given to the subdimensions of the scale, it is determined that the public students reach the highest mean in metacognitive strategies $(x=3.19)$. Also, it is observed that the highest average of private language course students is in metacognitive strategies $(x=3.51)$. Besides, it is seen that both the public $(x=2.84)$ and the private language course students $(x=$ 3.06) have the least preferred language learning strategies in affective strategies. 
Table 3. Level of self-regulated learning skills of participants

\begin{tabular}{lllll}
\hline & & $\mathbf{N}$ & $\overline{\mathbf{x}}$ & \multicolumn{1}{c}{ SD } \\
\hline \multirow{2}{*}{ Strategy use and evaluation } & Public & 289 & 3.75 & .62 \\
\cline { 2 - 5 } Planning and goal setting & Private & 124 & 3.81 & .54 \\
\hline \multirow{2}{*}{ Motivation and action for learning } & Public & 289 & 3.69 & .64 \\
\cline { 2 - 5 } & Private & 124 & 3.85 & .62 \\
\hline \multirow{2}{*}{ Mean } & Public & 289 & 3.92 & .61 \\
\cline { 2 - 5 } & Private & 124 & 3.99 & .68 \\
\hline
\end{tabular}

In Table 3, it is seen that the average point of self-regulation skills of the public students is 3.78 and the private language course students' is 3.87. The sub-dimensions of the scale show that the students in both groups have the highest mean in dimensions of motivation and action for learning.

3.2. Differences between Language Learning Strategies and Self-Regulated Learning Skills According to School Type

Table 4. Independent Sample T-test results of language learning strategies according to school type of the participants

\begin{tabular}{|c|c|c|c|c|c|c|c|}
\hline & & $\mathbf{N}$ & $\overline{\mathbf{x}}$ & sd & $\mathbf{t}$ & $\mathrm{p}$ & d \\
\hline \multirow{2}{*}{ Memory Strategies } & Public & 289 & 2.99 & .81 & \multirow{2}{*}{-5.740} & \multirow{2}{*}{.149} & \\
\hline & Private & 124 & 3.47 & .71 & & & \\
\hline \multirow{2}{*}{ Cognitive Strategies } & Public & 289 & 2.87 & .81 & \multirow{2}{*}{-5.075} & \multirow{2}{*}{$.020^{*}$} & \multirow{2}{*}{.56} \\
\hline & Private & 124 & 3.29 & .68 & & & \\
\hline \multirow{2}{*}{ Compensation Strategies } & Public & 289 & 3.07 & .78 & \multirow{2}{*}{-1.191} & \multirow{2}{*}{.919} & \\
\hline & Private & 124 & 3.18 & .69 & & & \\
\hline \multirow{2}{*}{ Meta Cognitive Strategies } & Public & 289 & 3.19 & .87 & \multirow{2}{*}{-3.581} & \multirow{2}{*}{$.018^{*}$} & \multirow[t]{2}{*}{.40} \\
\hline & Private & 124 & 3.51 & .74 & & & \\
\hline \multirow{2}{*}{ Affective Strategies } & Public & 289 & 2.84 & .79 & \multirow{2}{*}{-2.633} & \multirow{2}{*}{.340} & \\
\hline & Private & 124 & 3.06 & .75 & & & \\
\hline \multirow{2}{*}{ Social Strategies } & Public & 289 & 3.11 & .77 & \multirow{2}{*}{-2.011} & \multirow{2}{*}{.112} & \\
\hline & Private & 124 & 3.31 & .68 & & & \\
\hline \multirow{2}{*}{ Mean } & Public & 289 & 3.00 & .67 & \multirow{2}{*}{-4.683} & \multirow{2}{*}{.074} & \\
\hline & Private & 124 & 3.33 & .60 & & & \\
\hline
\end{tabular}

As seen in Table 4 above, according to the independent sample T-test results, there is no significant difference between the participants in terms of school type in such dimensions; memory strategies $(\mathrm{t} 413=-5.740, \mathrm{p}=.149)$, compensation strategies $(\mathrm{t} 413=-$ 
1.191, $\mathrm{p}=.919)$, affective strategies $(\mathrm{t} 413=-2.633, \mathrm{p}=.340)$, social strategies $(\mathrm{t} 413=-2.011$, $\mathrm{p}=.112)$, and total of the scale $(\mathrm{t} 413=-4.683, \mathrm{p}=.074)$. However, it is determined that the level of use of cognitive strategies of private language course students $(\bar{x}=3.29$, $\mathrm{sd}=$ .68) was significantly ( $413=-5.075, \mathrm{p}=020)$ different than public students $(\bar{x}=2.87$, $\mathrm{sd}=.81)$. Moreover, the mean of metacognitive strategies of language course students $(\bar{x}=3.51, \mathrm{sd}=.74)$ is significantly ( $\mathrm{t} 413=-3.581, \mathrm{p}=.018)$ higher than the public students $(\bar{x}=3.19, \mathrm{sd}=.87)$ like cognitive strategies. The effect sizes of the students' language learning strategies are determined with the Cohen $d$ coefficient. Accordingly, $56 \%$ of the difference in cognitive strategies and $40 \%$ of the difference in metacognitive strategies are derived from the school type variable.

The findings related to the differences between school types in self-regulated learning skills of the university prep class and private language course students are shown in the table below.

Table 5. Independent Sample T-test results of self-regulated learning skills according to school type of the participants

\begin{tabular}{|c|c|c|c|c|c|c|c|}
\hline & & $\mathbf{N}$ & $\overline{\mathbf{x}}$ & sd & $t$ & $p$ & d \\
\hline \multirow{2}{*}{ Strategy use and evaluation } & Public & 286 & 3.75 & .625 & \multirow{2}{*}{-.921} & \multirow{2}{*}{.358} & \\
\hline & Private & 128 & 3.81 & .542 & & & \\
\hline \multirow{2}{*}{ Planning and goal setting } & Public & 286 & 3.70 & .643 & \multirow{2}{*}{-2.274} & \multirow{2}{*}{$.023^{*}$} & \multirow{2}{*}{.03} \\
\hline & Private & 128 & 3.85 & .620 & & & \\
\hline \multirow{2}{*}{$\begin{array}{l}\text { Motivation and action for } \\
\text { learning }\end{array}$} & Public & 286 & 3.93 & .611 & \multirow{2}{*}{-.918} & \multirow{2}{*}{.359} & \\
\hline & Private & 128 & 3.99 & .677 & & & \\
\hline \multirow{2}{*}{ Mean } & Public & 286 & 3.78 & .509 & \multirow{2}{*}{-1.637} & \multirow{2}{*}{.102} & \\
\hline & Private & 128 & 3.87 & .521 & & & \\
\hline
\end{tabular}

As seen in Table 5 above, according to the independent sample T-test results of selfregulated learning skills of participants, there is no significant difference according to the school type in such dimensions; strategy use and evaluation (t414=-.921, $\mathrm{p}=.358$ ), motivation and action for learning ( $\mathrm{t} 414=-.918, \mathrm{p}=.359)$, and whole scale ( $\mathrm{t} 414=-1.637$, $\mathrm{p}=.102)$. Also, level of planning and goal setting of private language course students $(\bar{x}=3.85, \mathrm{sd}=.62)$ is significantly $(\mathrm{t} 414=-2.274, \mathrm{p}=.023)$ higher than the public students $(\bar{x}=3.70, \mathrm{sd}=.643)$. The effect sizes of the students' language learning strategies are determined with Cohen $d$ coefficient. Accordingly, 3\% of the difference in dimension of planning and goal setting is derived from the school type variable. 


\subsection{Differences between Language Learning Strategies and Self-Regulated} Learning Skills According to Gender

The findings related to the differences between school types in language learning strategies of the university prep class and private language course students are shown in Table 6 below

Table 6. Independent Sample T-test results of language learning strategies according to the gender of participants.

\begin{tabular}{llllllll}
\hline \multirow{2}{*}{ Memory Strategies } & & $\mathbf{N}$ & $\overline{\mathbf{x}}$ & $\mathbf{s d}$ & $\mathbf{t}$ & $\mathbf{p}$ & $\mathbf{d}$ \\
\hline \multirow{2}{*}{ Cognitive Strategies } & Female & 213 & 3.23 & .76 & 2.281 & $.023^{*}$ & .22 \\
& Male & 209 & 3.05 & .84 & & & \\
\hline \multirow{2}{*}{ Compensation Strategies } & Female & 213 & 3.05 & .75 & 1.412 & .159 & \\
& Male & 209 & 2.94 & .83 & & & \\
\hline \multirow{2}{*}{ Meta Cognitive Strategies } & Female & 213 & 3.11 & .73 & .065 & .948 & \\
& Male & 209 & 3.10 & 1.01 & & & \\
\hline \multirow{2}{*}{ Affective Strategies } & Female & 213 & 3.38 & .85 & 2.151 & $.032^{*}$ & .21 \\
& Male & 209 & 3.20 & .83 & & & \\
\hline \multirow{2}{*}{ Social Strategies } & Female & 213 & 2.92 & .79 & .248 & .804 & \\
& Male & 209 & 2.90 & .78 & & & \\
\hline \multirow{2}{*}{ Whole Scale } & Female & 213 & 3.20 & .71 & .613 & .540 & \\
& Male & 209 & 3.15 & 1.02 & & & \\
\hline
\end{tabular}

As it can be seen in Table 6 above, according to the independent sample T-test results, there is no significant difference between the participants' gender in such dimensions; cognitive strategies $(\mathrm{t} 410=1.412, \mathrm{p}=.159)$, compensation strategies $(\mathrm{t} 410=.065, \mathrm{p}=.948)$, affective strategies $(\mathrm{t} 410=.248, \mathrm{p}=.804)$, social strategies $(\mathrm{t} 410=.613, \mathrm{p}=.540)$, and whole scale $(\mathrm{t} 410=1.631, \mathrm{p}=.104)$. Besides, it is seen that the mean of memory strategies of the female students ( $\bar{x}=3.23$, $\mathrm{sd}=.76$ ) differs significantly ( $\mathrm{t} 410=2.281, \mathrm{p}=.023$ ) compared to male students $(\bar{x}=3.05, \mathrm{sd}=.84)$. Also, metacognitive strategies of the female students $(\bar{x}=3.38$, sd $=.85)$ differs significantly $(\mathrm{t} 410=2.151, \mathrm{p}=.032)$ compared to male students $(\bar{x}$ $=3.20, \mathrm{sd}=.83$ ). The effect sizes of the students' language learning strategies are determined with Cohen $\mathrm{d}$ coefficient. Accordingly, 22\% of the difference in memory 
strategies and $21 \%$ of the difference in metacognitive strategies are derived from gender.

The findings related to the differences between school types in self-regulated learning skills of the public and private language course students are shown in Table 7 below.

Table 7. Independent Sample T-test results of self-regulated according to the gender of participants.

\begin{tabular}{lllllllll}
\hline & & $\mathbf{N}$ & $\overline{\mathbf{x}}$ & $\mathbf{s d}$ & $\mathbf{t}$ & $\mathbf{p}$ & $\mathbf{d}$ \\
\hline \multirow{2}{*}{ Strategy use and evaluation } & Female & 209 & 3.86 & .573 & & & \\
\cline { 2 - 7 } & Male & 205 & 3.68 & .615 & & & \\
\hline \multirow{2}{*}{ Planning and goal setting } & Female & 209 & 3.84 & .585 & & & \\
\cline { 2 - 7 } & Male & 205 & 3.65 & .678 & & & \\
\hline Motivation and action for & Female & 209 & 3.96 & .602 & .561 & .575 & \\
learning & Male & 205 & 3.93 & .663 & & & \\
\hline \multirow{2}{*}{ Whole Scale } & Female & 209 & 3.88 & .488 & 2.979 & $.003 *$ & $\mathbf{. 0 3}$ \\
& Male & 205 & 3.73 & .529 & & & \\
\hline
\end{tabular}

As it can be seen in Table 7, there is no significant difference between males and females in motivation and action for learning dimension ( $\mathrm{t} 414=.561, \mathrm{p}=.575)$. In addition, it is seen that the planning and goal setting of the female students $(\bar{x}=3.84$, $\mathrm{sd}=.585)$ differs significantly ( $\mathrm{t} 414=3.125, \mathrm{p}=.002)$ compared to male students $(\bar{x}=3.65$, $\mathrm{sd}=.678)$. Also, strategy use and evaluation of female students $(\bar{x}=3.86, \mathrm{sd}=.573)$ is significantly different and higher $(\mathrm{t} 414=3.112, \mathrm{p}=.002)$ than the male students $(\bar{x}=3.68$, $\mathrm{sd}=.615)$. Finally, female students' mean $(\bar{x}=3.88, \mathrm{sd}=.488)(\bar{x}=3.73$, sd=.529) of selfregulated learning skills is significantly different and higher $(\mathrm{t} 414=2.979, \mathrm{p}=.003)$ than males in the whole scale. The effect sizes of the students' language learning strategies are determined with Cohen $d$ coefficient. Accordingly, 3\% of the difference in the whole scale and the other dimensions are derived from gender. 


\section{4. Differences between Language Learning Strategies and Self-Regulated Learning Skills According to Graduated High School Type}

The findings related to the differences between language learning strategies and selfregulation skills of public university students and private language course students according to the high school type they have graduated are shown below.

Table 8. ANOVA results related to the comparison of the language learning strategy levels of participants depending on the type of graduated high school

\begin{tabular}{|c|c|c|c|c|c|c|c|}
\hline Dimensions & Source of Variance & $\begin{array}{l}\text { Squares } \\
\text { Total }\end{array}$ & Df & $\begin{array}{l}\text { Squares } \\
\text { Average }\end{array}$ & $\mathbf{F}$ & $p$ & $\eta 2$ \\
\hline \multirow{3}{*}{$\begin{array}{l}\text { Memory } \\
\text { Strategies }\end{array}$} & Between Groups & 5.859 & 5 & 1.172 & \multirow{3}{*}{1.775} & \multirow{3}{*}{.117} & \\
\hline & Within Groups & 266.630 & 404 & .660 & & & \\
\hline & Total & 272.489 & 409 & & & & \\
\hline \multirow{3}{*}{$\begin{array}{l}\text { Cognitive } \\
\text { Strategies }\end{array}$} & Between Groups & 5.845 & 5 & 1.169 & \multirow{3}{*}{1.830} & \multirow{3}{*}{.106} & \\
\hline & Within Groups & 258.026 & 404 & .639 & & & \\
\hline & Total & 263.872 & 409 & & & & \\
\hline \multirow{3}{*}{$\begin{array}{l}\text { Compensation } \\
\text { Strategies }\end{array}$} & Between Groups & 11.181 & 5 & 2.236 & \multirow{3}{*}{2.918} & \multirow{3}{*}{$.013^{*}$} & \multirow{3}{*}{.03} \\
\hline & Within Groups & 309.572 & 404 & .766 & & & \\
\hline & Total & 320.753 & 409 & & & & \\
\hline \multirow{3}{*}{$\begin{array}{l}\text { Metacognitive } \\
\text { Strategies }\end{array}$} & Between Groups & 8.259 & 5 & 1.652 & \multirow{3}{*}{2.296} & \multirow{3}{*}{$.045^{*}$} & \multirow{3}{*}{.03} \\
\hline & Within Groups & 289.873 & 404 & .719 & & & \\
\hline & Total & 298.132 & 409 & & & & \\
\hline \multirow{3}{*}{$\begin{array}{l}\text { Affective } \\
\text { Strategies }\end{array}$} & Between Groups & 3.148 & 5 & .630 & \multirow{3}{*}{1.015} & \multirow{3}{*}{.408} & \\
\hline & Within Groups & 249.886 & 404 & .620 & & & \\
\hline & Total & 253.034 & 409 & & & & \\
\hline \multirow{3}{*}{$\begin{array}{l}\text { Social } \\
\text { Strategies }\end{array}$} & Between Groups & 2.282 & 5 & .456 & \multirow{3}{*}{.583} & \multirow{3}{*}{.713} & \\
\hline & Within Groups & 315.487 & 404 & .783 & & & \\
\hline & Total & 317.770 & 409 & & & & \\
\hline \multirow{3}{*}{ Whole Scale } & Between Groups & 4.102 & 5 & .820 & \multirow{3}{*}{1.848} & \multirow{3}{*}{.103} & \\
\hline & Within Groups & 179.386 & 404 & .444 & & & \\
\hline & Total & 183.489 & 409 & & & & \\
\hline
\end{tabular}

As it is seen in Table 8 , there is no statistically significant difference between the dimensions of memory $(\mathrm{F}=1.775 . \mathrm{p}=.117)$, cognitive $(\mathrm{F}=1.830, \mathrm{p}=.106)$, affective $(\mathrm{F}=1.015$, $\mathrm{p}=.408)$, social strategies $(\mathrm{F}=.583, \mathrm{p}=.713)$, the whole scale $(\mathrm{F}=1.848, \mathrm{p}=.103)$ and type of 
graduated high school. However, it is seen that there is a significant difference in compensation $(\mathrm{F}=2.918, \mathrm{p}=.013)$ and metacognitive strategies $(\mathrm{F}=2.296, \mathrm{p}=.045)$. The homogeneity of the variance is tested in the areas where there are significant differences, and it is founded that the variance is not homogeneous in the compensation strategies (Levene $\mathrm{F}=3.55, \mathrm{p}=.005$ ); therefore, Games-Howell pairwise comparison test is used in Post Hoc tests. Consequently, a significant difference is found between the Anatolian High School ( $x=3.35)$ and General High School $(x=2.88)$ and Vocational High School ( $x=3.43)$ graduates in favour of Vocational High School graduates. However, in metacognitive strategies where there is another difference, it is seen that the variance is equally distributed (Levene $F=1.884, p=.096$ ). As a result of the analysis, a significant difference is found between the Anatolian Teacher Training High School $(x=2.84)$ and General High School $(x=2.88)$ and Vocational High School $(x=3.43)$ graduates in favour of Vocational High School graduates.

Table 9. ANOVA results related to the comparison of the self-regulated learning skills of participants depending on the type of graduated high school

\begin{tabular}{|c|c|c|c|c|c|c|c|}
\hline Dimensions & $\begin{array}{l}\text { Source of } \\
\text { Variance }\end{array}$ & $\begin{array}{l}\text { Squares } \\
\text { Total }\end{array}$ & Df & $\begin{array}{l}\text { Squares } \\
\text { Average }\end{array}$ & $\mathbf{F}$ & $p$ & $\eta 2$ \\
\hline \multirow{3}{*}{$\begin{array}{l}\text { Strategy use } \\
\text { and evaluation }\end{array}$} & Between Groups & 2.886 & 5 & .577 & \multirow{3}{*}{1.613} & \multirow{3}{*}{.155} & \\
\hline & Within Groups & 146.004 & 408 & .358 & & & \\
\hline & Total & 148.891 & 413 & & & & \\
\hline \multirow{3}{*}{$\begin{array}{l}\text { Planning and } \\
\text { goal setting }\end{array}$} & Between Groups & 2.215 & 5 & .443 & \multirow{3}{*}{1.085} & \multirow{3}{*}{.368} & \\
\hline & Within Groups & 166.536 & 408 & .408 & & & \\
\hline & Total & 168.751 & 413 & & & & \\
\hline \multirow{3}{*}{$\begin{array}{l}\text { Motivation and } \\
\text { action for } \\
\text { learning }\end{array}$} & Between Groups & 2.538 & 5 & .508 & \multirow{3}{*}{1.274} & \multirow{3}{*}{.274} & \\
\hline & Within Groups & 162.489 & 408 & .398 & & & \\
\hline & Total & 165.027 & 413 & & & & \\
\hline \multirow{3}{*}{ Whole Scale } & Between Groups & 2.232 & 5 & .446 & \multirow{3}{*}{1.708} & \multirow{3}{*}{.132} & \\
\hline & Within Groups & 106.667 & 408 & .261 & & & \\
\hline & Total & 108.900 & 413 & & & & \\
\hline
\end{tabular}

Table 9 shows the results of one-way analysis of variance towards the scores obtained from the public and private language course students self-regulatory learning skills 
scale according to the type of graduated high school. As it is seen in the table, there is not any statistically significant difference among the dimensions and all over the scale.

\subsection{Differences between Language Learning Strategies and Self-Regulated Learning Skills According to Proficiency Levels}

The findings related to the differences between language learning strategies and selfregulation skills of public and private language course students according to their proficiency levels are shown below.

Table 10. ANOVA results related to the comparison of the language learning strategies of participants depending on their proficiency levels

\begin{tabular}{|c|c|c|c|c|c|c|c|}
\hline Dimensions & $\begin{array}{l}\text { Source of } \\
\text { Variance }\end{array}$ & $\begin{array}{l}\text { Squares } \\
\text { Total }\end{array}$ & df & $\begin{array}{l}\text { Squares } \\
\text { Average }\end{array}$ & $\mathbf{F}$ & $p$ & $\eta 2$ \\
\hline \multirow{3}{*}{$\begin{array}{l}\text { Memory } \\
\text { Strategies }\end{array}$} & Between Groups & 2.738 & 3 & .913 & \multirow{3}{*}{1.420} & \multirow{3}{*}{.236} & \\
\hline & Within Groups & 255.081 & 397 & .643 & & & \\
\hline & Total & 257.819 & 400 & & & & \\
\hline \multirow{3}{*}{$\begin{array}{l}\text { Cognitive } \\
\text { Strategies }\end{array}$} & Between Groups & 12.281 & 3 & 4.094 & \multirow{3}{*}{6.911} & \multirow{3}{*}{$.000^{*}$} & \multirow{3}{*}{.05} \\
\hline & Within Groups & 235.139 & 397 & .592 & & & \\
\hline & Total & 247.420 & 400 & & & & \\
\hline \multirow{3}{*}{$\begin{array}{l}\text { Compensation } \\
\text { Strategies }\end{array}$} & Between Groups & 4.978 & 3 & 1.659 & \multirow{3}{*}{2.982} & \multirow{3}{*}{$.031^{*}$} & \multirow{3}{*}{.02} \\
\hline & Within Groups & 220.895 & 397 & .556 & & & \\
\hline & Total & 225.874 & 400 & & & & \\
\hline \multirow{3}{*}{$\begin{array}{l}\text { Metacognitive } \\
\text { Strategies }\end{array}$} & Between Groups & 5.654 & 3 & 1.885 & \multirow{3}{*}{2.793} & \multirow{3}{*}{$.040^{*}$} & \multirow{3}{*}{.02} \\
\hline & Within Groups & 267.182 & 396 & .675 & & & \\
\hline & Total & 272.836 & 399 & & & & \\
\hline \multirow{3}{*}{$\begin{array}{l}\text { Affective } \\
\text { Strategies }\end{array}$} & Between Groups & 1.457 & 3 & .486 & \multirow{3}{*}{.815} & \multirow{3}{*}{.486} & \\
\hline & Within Groups & 235.925 & 396 & .596 & & & \\
\hline & Total & 237.382 & 399 & & & & \\
\hline \multirow{3}{*}{$\begin{array}{l}\text { Social } \\
\text { Strategies }\end{array}$} & Between Groups & 2.080 & 3 & .693 & \multirow{3}{*}{1.300} & \multirow{3}{*}{.274} & \\
\hline & Within Groups & 211.086 & 396 & .533 & & & \\
\hline & Total & 213.166 & 399 & & & & \\
\hline \multirow{3}{*}{ Whole Scale } & Between Groups & 4.444 & 3 & 1.481 & \multirow{3}{*}{3.723} & \multirow{3}{*}{$.012^{*}$} & \multirow{3}{*}{.03} \\
\hline & Within Groups & 157.979 & 397 & .398 & & & \\
\hline & Total & 162.423 & 400 & & & & \\
\hline
\end{tabular}


Table 10 shows the results of one-way analysis of variance towards the scores obtained from the public and private language course students' language learning strategies according to the proficiency levels. It is seen that there is not any statistically significant difference in the dimensions of memory strategies ( $\mathrm{F}=1.420, \mathrm{p}=.236)$, affective strategies $(\mathrm{F}=.815, \mathrm{p}=.486)$, and social strategies $(\mathrm{F}=1.300, \mathrm{p}=.274)$. However, it is found that there are significant differences in cognitive $(\mathrm{F}=6.911, \mathrm{p}=.0)$, compensation $(\mathrm{F}=2.982, \mathrm{p}=.031)$, metacognitive strategies $(\mathrm{F}=2.793, \mathrm{p}=.040)$, and all over the scale $(\mathrm{F}=3.723, \mathrm{p}=.012)$. The homogeneity of the variance is tested in the areas where there are significant differences, and it is founded that the variance is not homogeneous in the cognitive strategies (Levene F=2.859, $\mathrm{p}=.037$ ); therefore, Games-Howell pairwise comparison test is used in Post Hoc tests.

And it is observed that there is a significant difference in cognitive strategies among the A1 $(x=2.80)$ and A2 ( $x=2.99)$ and B1 $(x=3.28)$ students in favour of the participants who are in B1 proficiency level. Also, a significant difference in metacognitive strategies is found among the $A 1(x=3.23)$ and $A 2(x=3.27)$ and $B 1(x=3.49)$ students in favour of the participants who are in B1 proficiency level. Finally, it is observed that there is a significant difference all over the scale among the A1 ( $x=3.00)$ and A2 ( $x=3.09)$ and B1 ( $\mathrm{x}=3.27)$ students in favour of the participants who are in B1 proficiency level. 
Table 11. ANOVA results related to the comparison of the self-regulated learning skills of participants depending on their proficiency levels

\begin{tabular}{|c|c|c|c|c|c|c|c|}
\hline Dimensions & Source of Variance & $\begin{array}{l}\text { Squares } \\
\text { Total }\end{array}$ & $\mathrm{df}$ & $\begin{array}{l}\text { Squares } \\
\text { Average }\end{array}$ & $\mathrm{F}$ & $p$ & $\begin{array}{l}\eta \\
2\end{array}$ \\
\hline \multirow{3}{*}{$\begin{array}{l}\text { Strategy use and } \\
\text { evaluation }\end{array}$} & Between Groups & ,461 & 3 & .154 & \multirow{3}{*}{.425} & \multirow{3}{*}{.736} & \\
\hline & Within Groups & 148.429 & 410 & .362 & & & \\
\hline & Total & 148.891 & 413 & & & & \\
\hline \multirow{3}{*}{$\begin{array}{l}\text { Planning and } \\
\text { goal setting }\end{array}$} & Between Groups & .371 & 3 & .124 & \multirow{3}{*}{.301} & \multirow{3}{*}{.825} & \\
\hline & Within Groups & 168.380 & 410 & .411 & & & \\
\hline & Total & 168.751 & 413 & & & & \\
\hline \multirow{3}{*}{$\begin{array}{l}\text { Motivation and } \\
\text { action for } \\
\text { learning }\end{array}$} & Between Groups & .455 & 3 & .152 & \multirow{3}{*}{.378} & \multirow{3}{*}{.769} & \\
\hline & Within Groups & 164.572 & 410 & .401 & & & \\
\hline & Total & 165.027 & 413 & & & & \\
\hline \multirow{3}{*}{ Whole Scale } & Between Groups & .147 & 3 & .049 & \multirow{3}{*}{.184} & \multirow{3}{*}{.907} & \\
\hline & Within Groups & 108.753 & 410 & .265 & & & \\
\hline & Total & 108.900 & 413 & & & & \\
\hline
\end{tabular}

Table 11 shows the results of one-way analysis of variance towards the scores obtained from the public and private language course students self-regulatory learning skills scale according to their proficiency levels. As it is seen in the table, there is not any statistically significant difference among the dimensions and all over the scale.

\subsection{Differences between Language Learning Strategies and Self-Regulated Learning Skills According to Frequency of English Use}

Participants were asked to indicate their frequency of use in English on the questionnaire. The findings related to the differences between language learning strategies and self-regulation skills of public and private language course students according to their frequency of English use are shown below. 
Table 12. ANOVA results related to the comparison of the language learning strategies of participants depending on their frequency of English use

\begin{tabular}{|c|c|c|c|c|c|c|c|}
\hline Dimensions & Source of Variance & $\begin{array}{l}\text { Squares } \\
\text { Total }\end{array}$ & $\mathrm{df}$ & $\begin{array}{l}\text { Squares } \\
\text { Average }\end{array}$ & $\mathrm{F}$ & $p$ & $\eta 2$ \\
\hline \multirow{3}{*}{$\begin{array}{l}\text { Memory } \\
\text { Strategies }\end{array}$} & Between Groups & 10.442 & 4 & 2.611 & \multirow[t]{3}{*}{4.176} & \multirow[t]{3}{*}{$.003^{*}$} & \multirow{3}{*}{.04} \\
\hline & Within Groups & 247.573 & 396 & .625 & & & \\
\hline & Total & 258.015 & 400 & & & & \\
\hline \multirow{3}{*}{$\begin{array}{l}\text { Cognitive } \\
\text { Strategies }\end{array}$} & Between Groups & 15.828 & 4 & 3.957 & \multirow[t]{3}{*}{6.769} & \multirow[t]{3}{*}{$.000^{*}$} & \multirow{3}{*}{.06} \\
\hline & Within Groups & 231.504 & 396 & .585 & & & \\
\hline & Total & 247.332 & 400 & & & & \\
\hline \multirow{3}{*}{$\begin{array}{l}\text { Compensation } \\
\text { Strategies }\end{array}$} & Between Groups & 8.919 & 4 & 2.230 & \multirow[t]{3}{*}{4.082} & \multirow{3}{*}{$.003^{*}$} & \multirow{3}{*}{.04} \\
\hline & Within Groups & 216.321 & 396 & .546 & & & \\
\hline & Total & 225.240 & 400 & & & & \\
\hline \multirow{3}{*}{$\begin{array}{l}\text { Metacognitive } \\
\text { Strategies }\end{array}$} & Between Groups & 25.751 & 4 & 6.438 & \multirow[t]{3}{*}{10.306} & \multirow[t]{3}{*}{$.000^{*}$} & \multirow{3}{*}{.09} \\
\hline & Within Groups & 246.733 & 396 & .625 & & & \\
\hline & Total & 272.484 & 400 & & & & \\
\hline \multirow{3}{*}{$\begin{array}{l}\text { Affective } \\
\text { Strategies }\end{array}$} & Between Groups & 3.116 & 4 & .779 & \multirow[t]{3}{*}{1.308} & \multirow[t]{3}{*}{.267} & \\
\hline & Within Groups & 235.306 & 396 & .596 & & & \\
\hline & Total & 238.422 & 400 & & & & \\
\hline \multirow{3}{*}{$\begin{array}{l}\text { Social } \\
\text { Strategies }\end{array}$} & Between Groups & 4.313 & 4 & 1.078 & \multirow[t]{3}{*}{2.023} & \multirow[t]{3}{*}{.091} & \\
\hline & Within Groups & 210.595 & 396 & .533 & & & \\
\hline & Total & 214.908 & 400 & & & & \\
\hline \multirow{3}{*}{ Whole Scale } & Between Groups & 11.092 & 4 & 2.773 & \multirow{3}{*}{7.245} & \multirow{3}{*}{$.000^{*}$} & \multirow{3}{*}{.07} \\
\hline & Within Groups & 151.566 & 396 & .383 & & & \\
\hline & Total & 162.658 & 400 & 2.611 & & & \\
\hline
\end{tabular}

Table 12 shows the results of one-way analysis of variance towards the scores obtained from the public and private language course students' language learning strategies according to the frequency of English use. It is found out that there is not any significant difference in affective $(\mathrm{F}=1.308, \mathrm{p}=.267)$ and social strategies $(\mathrm{F}=2.023$, $\mathrm{p}=.091)$. However, it is seen that there are significant differences in memory $(\mathrm{F}=4.176$, $\mathrm{p}=.003)$, cognitive $(\mathrm{F}=6.769, \mathrm{p}=.0)$, compensation $(\mathrm{F}=4.082, \mathrm{p}=.04)$, metacognitive 
strategies $(F=10.306, p=.0)$, and all over the scale $(F=7.245, p=.07)$. And it is observed that there is a significant difference all over the scale among the "often" $(x=3.48)$ and "sometimes" ( $x=3.11)$ and "rarely" $(x=3.00)$ students in favour of the participants who claim that they use English "often".

\subsection{Correlation between Language Learning Strategies and Self-Regulated Learning Skills}

Table 13. Correlation between language learning strategies and self-regulated learning skills

\begin{tabular}{lll}
\hline & $\begin{array}{c}\text { Language learning } \\
\text { strategies }\end{array}$ & \multicolumn{1}{c}{$\begin{array}{c}\text { Self-regulated learning } \\
\text { skills }\end{array}$} \\
\hline Language learning strategies & 1 & $.54^{* *}$ \\
\hline Self-regulated learning skills & $.54^{* *}$ & 1 \\
\hline
\end{tabular}

Table 13 shows that there is a significant and positive correlation between language learning strategies and self-regulated learning skills $(r=.54, p=.0)$.

\section{Discussion \& Conclusion}

In this study, it was aimed is examine the language learning strategy use and selfregulatory skills of the learners attending university preparatory class and private language learning course, focusing on their foreign language learning strategies and self-regulation skills. According to the SILL scores, both groups have mid-level strategy use; however, it is seen that the average of private language course students is higher than the preparatory class students. This result confirms the other research in the literature (Altan, 2004; Bekleyen, 2006; Cesur, 2008; Chang, 2011; Padem, 2012; Tang and Tian, 2015; Wong, 2011). These studies show that learners have some kind of strategy use, but that is not so high. Sub-dimensions of the scale show that metacognitive strategies are the most preferred by both groups. This finding supports other studies in the literature (Ada, 2011; Park, 2006). However, other studies show that social strategies are preferred intensively by learners (Padem, 2012; Rao,2016; Wong, 2011).

The fact that affective strategies are the least preferred strategy by the learners in both groups confirms the research in the literature (Hong-Nam and Leavell, 2006; Padem, 2012; Razak et al., 2012; Ünal et al., 2011; Wong, 2011). According to Lestari and Yahyudin (2020) learners rarely use affective strategies since they do not pay attention too much to emotional factors such as anxiety and nervousness while they are learning English. Taylor and Cutler (2016) stated that students at the intermediate level use 
metacognitive strategies more, as they got more specialized in language learning, which helps them to control their autonomy better and evaluate their learning more frequently. Likewise, Meniado (2016) explained that the use of metacognitive strategy is more common among students at an intermediate level than the beginners. Because learning barriers of these learners decrease in time and that helps them to use their metacognition better. He also explained that the learning environment determines the use of metacognitive strategies. Oxford (1990) stated that cognitive strategies are the most preferred strategy for beginners of foreign languages because they do not know much about the target language. It has been determined that students of private courses have a higher average in terms of cognitive strategies such as summarizing the text read or finding English patterns and metacognition strategies such as selfevaluation or time allocation for learning English than preparatory class students. There are no studies on language learning strategies of private language course students in the literature; therefore, the results of the present study will be a reference for further studies. However, Jimenez et al. (1991) reported that students in private schools in the Philippines had higher levels of strategy use than students in public schools. Comparing the SILL scores of the two groups shows that there is no significant difference between the two groups except cognitive and metacognitive strategies. Ergun (2011) examined the students' language learning concerns in public and private universities and stated that there was no significant difference between the language learning anxieties of the students in the two institutions.

Although the averages of female students are higher than males in the use of language learning strategies, not no statistically significant difference is found. Similar studies conducted in the literature that confirm the results of the present study show that there is no significant difference between the two genders (Batumlu \& Erden, 2007; Cesur, 2008; Ertekin, 2006; Hong-Nam and Leavell, 2006; Padem, 2011; Tabanlığlu, 2003). Also, there are other studies showing that there are significant differences in favour of female students (Aslan, 2009; Liyanage \& Bartlett, 2011; Nyikos, 1990; Oxford, 1993; Razak et al., 2012; Shaw \& Oxford, 1995) and male students (Phakiti, 2003; Tang \& Tian, 2015). The relationship between self-regulatory learning skills and gender shows that females have higher average scores than males all over the scale and all dimensions except planning and goal setting. Besides, other studies have shown that female students have more self-regulation skills than males (Aktan, 2012; Bidjenaro, 2005; Vrugt \& Oort, 2010; Zimmerman \& Martinez-Pons, 1990). Lin, Zhang and Zheng 
(2017) stated that self-regulation was a medium role between learning strategy and success,

In the use of language learning strategy, it is found that there are significant differences between students who are in B1 and B2 proficiency levels and students in A1 and A2 in favour of upper-level students. Accordingly, students who are in the upper levels use language-learning strategies more, also it can be said that the use of language learning strategy contributes to improving the English language. Moreover, there are significant differences in cognitive, metacognitive, and compensation strategies. There are similar studies that support this result in the literature (Bremner, 1999; Oxford \& Nyikos, 1989; Wharton, 2000).

Then, it is found out that there are differences in terms of language learning strategies among students, hence, the more English use brings about the more strategy use. The literature shows that there is no study examining the language learning strategies and frequency of English using; in this respect, the findings obtained from this research will be a source for other studies. Although not directly related to language learning strategies, some studies are showing that the level of use of English results in increasing the proficiency levels (Belcher, 2006; Harmer, 1991; Liu et al., 2004). There is a significant and positive correlation between language learning strategies and selfregulated learning skills. According to this finding, it can be said that as the selfregulatory learning skills of the students increased, the levels of language learning strategies also increased. There are studies in the literature supporting that result (Dianyu, 2005; Chularut \& DeBacker, 2004; Xiaodong, 2004).

To conclude, private language course students have higher scores than prep class students in all dimensions and all over the scale of language learning strategies. There are, of course, other variables that affect strategy use, but it can be said that private language course students are more aware of the strategy use in language learning. To explain this difference more, especially qualitative, studies are required. Because private language courses are not obligatory, instead voluntarily, the students may have a deeper intrinsic motivation. One of the main purposes of this study was to probe whether learners with different self-regulation skills differed in their use of language learning strategies. The results showed that learners who possessed a higher level of self-regulation reported using learning strategies more often than those who did not possess this higher level in both institutions. Thus, learners get to be encouraged to use language learning strategies and self-regulation skills. 


\section{Suggestions}

It is determined that the students use language-learning strategies at an intermediate level. To increase that, teachers should inform students about the use of strategy in their lessons and encourage them to use language learning strategies. In particular, students having lower proficiency are seen to have low strategy use, so they should be informed and encouraged to use language learning strategies. It is seen that private language course students have higher scores in both inventories of language learning strategies and the scale of self-regulatory learning skills. The facilities of public and private language course students show that there is not much difference between them, it is thought that the only difference is in class size and the course materials used. Consequently, it may be useful to decrease the number of students in classes. Participants were not asked whether they had previously received any training beforehand about language learning strategies and self-regulatory learning skills, thus it is important to ask that to reveal whether there is any difference according to the training. Furthermore, it is observed in the present study that female students have more self-regulatory learning skills than males. However, no data have been obtained about the reasons for this, so the self-regulation skills of female and male students can be explored in depth. 


\section{References}

Ada, S. (2011). A study on language learning strategies of students in private primary schools [Yayımlanmamış yüksek lisans tezi]. Trakya Üniversitesi Sosyal bilimler Enstitüsü.

Akıllılar, T. \& Uslu, Z. (2011). Almanca bölümü öğrencilerinin uyguladıkları dil öğrenme stratejileri. Çukurova Üniversitesi Eğitim Fakültesi Dergisi,2(40), 24-37. https://bit.ly/3sVWVT4

Akın, A. (2001). Improving students' active vocabulary in English through strategy awareness, recycling, and student feedback [Unpublished master's thesis]. METU Social Sciences Institute.

Aktan, S. (2012). Öğrencilerin akademik başarısı, öz düzenleme becerisi, motivasyonu ve öğretmenlerinin öğretim stilleri arasındaki ilişki [Yayımlanmamış doktora tezi] Balıkesir Üniversitesi Sosyal Bilimler Enstitüsü.

Akyol, S., \& Fer, S. (2010). Sosyal yapılandırmacı öğrenme ortamı tasarımının öğrenenlerin akademik başarılarına ve öğrenmenin kalıcılığına etkisi nedir? In International Conference on New Trends in Education and Their Implications( Vol. 11, p. 13). http://www.iconte.org/FileUpload/ks59689/File/193.pdf

Altan, M. Z. (2004). Nationality and language learning strategies of ELT-Major University Students. Asian EFL Journal, 6(2), 1-11. https://bit.ly/3tR9X5K

Anderson, N. J. (1991). Individual differences in strategy use in second language reading and testing. The modern language journal, 75(4), 460-472. https://doi.org/10.2307/329495

Aslan, O. (2009). The role of gender and language learning strategies in learning English. [Unpublished master's thesis] METU Social Sciences Institute.

Ayhan, Ü. (2016). The use of language learning strategies and its relationship with personality traits and individual differences: The case of Bosnian students at a private university [Unpublished PHD thesis]. International Burch University, Education Faculty.

Bacon, S. M. (1992). The relationship between gender, comprehension, processing strategies, and cognitive and affective response in foreign language listening. The modern language Journal, 76(2), 160-178. https://doi.org/10.1111/j.15404781.1992.tb01096.x

Barnhardt, S., Chamot, A. U., El-Dinary, P. B., \& Robbins, J. (1999). Learning strategies handbook. Addison-Wesley Longman. 
Baş, G. (2014). Lise öğrencilerinin dil öğrenme stratejileri ile İngilizce dersindeki akademik başarıları arasındaki ilişki. Dokuz Eylül Üniversitesi Buca Eğitim Fakültesi Dergisi, (37), 166-180. https://dergipark.org.tr/tr/pub/deubefd/issue/25112/265124

Batumlu, D. Z., \& Erden, M. (2007). The relationship between foreign language anxiety and English achievement of Yıldız Technical University School of foreign languages preparatory students. Journal of theory and practice in education, 3(1), 24-38. https://dergipark.org.tr/tr/download/article-file/63258

Bedell, D. A., \& Oxford, R. L. (1996). Cross-cultural comparisons of language learning strategies in the People's Republic of China and other countries. Language learning strategies around the world: Cross-cultural perspectives, 47-60.

Bekleyen, N. (2006). İngilizce öğretmen adaylarının dil öğrenme stratejileri kullanımı. TÖMER Dil Dergisi, 132, 28-37. https://bit.ly/3nnzIfp

Belcher, D. D. (2006). English for specific purposes: Teaching to perceived needs and imagined futures in worlds of work, study, and everyday life. TESOL quarterly, 133-156. https://doi.org/10.2307/40264514

Bidjenaro, T. (2005). Gender Differences in Self Regulated Learning. Paper Presented at the 36th/2005 Annual Meeting of the Northeastern Educational Research Association. Kerhonkson, NY.ED 490777

Bremner, S. (1999). Language learning strategies and language proficiency: Investigating the relationship in Hong Kong. Canadian Modern Language Review, 55(4), 490-514. https://doi.org/10.3138/cmlr.55.4.490

Büyüköztürk, Ş., Çakmak, E. K., Akgün, Ö. E., \& Demirel, F. (2018). Bilimsel araştırma yöntemleri (25.Baskl). Pegem Akademi.

Carrell, P. L. (1998). Can reading strategies be successfully taught?. Australian Review of Applied Linguistics, 21, 1-20. https://doi.org/10.1075/aral.21.1.01car

Cesur, M. O. (2008). Üniversite hazırlık sınıfı öğrencilerinin yabancı dil öğrenme stratejileri, öğrenme stili tercihi ve yabancı dil akademik başarısı arasındaki açıklayıcı ve yordayıcı ilişkiler örüntüsü [ Yayımlanmamış doktora tezi].YTÜ Sosyal Bilimler Enstitüsü.

Cesur, M. O., \& Fer, S. (2007). What is the validity and reliability study of the strategy inventory of language learning. Yüzüncü Yll Üniversitesi Eğitim Fakültesi Dergisi, 4(2), 4974. https://bit.ly/3gEVs11 
Chamot, A. U. (1993). Student responses to learning strategy instruction in the foreign language classroom. Foreign Language Annals, 26(3), 308. https://doi.org/10.1111/j.19449720.1993.tb02288.x

Chang, Y. F. (2011). Refusing in a foreign language: An investigation of problems encountered by Chinese learners of English. http://dx.doi.org/10.1515/mult.2011.004

Chularut, P., \& DeBacker, T. K. (2004). The influence of concept mapping on achievement, self-regulation, and self-efficacy in students of English as a second language. Contemporary Educational Psychology, 29(3), 248-263. http://dx.doi.org/10.1016/j.cedpsych.2003.09.001

Cohen, A. D. (2003). The learner's side of foreign language learning: Where do styles, strategies, and tasks meet?. IRAL, International Review of Applied Linguistics in Language Teaching, 41(4), 279-292. https://doi.org/10.1515/iral.2003.013

Cohen, A. D., \& Dörnyei, Z. (2002). Focus on the language learner: Motivation, styles, and strategies. An introduction to applied linguistics, 170-190. Routledge.

Creswell, J. W. (2013). Research design: Qualitative, quantitative, and mixed methods approaches (4th edition). Sage publications.

Çelik, N. (2012) Matematik öğretmen adaylarının ve matematik öğretmenlerinin öz düzenleme becerilerinin ve öz yeterlik algılarının incelenmesi [Yayımlanmamış yüksek lisans tezi]. Atatürk Üniversitesi, Eğitim Bilimleri Enstitüsü.

Çetinel, E. (2009). 30 bin kişi 50 milyon TL verip kursa gidiyor, sadece yüzde 25'i tamamlyor. http://www.radikal.com.tr/ekonomi/30-bin-kisi-50-milyon-tl-verip-kursa-gidiyorsadece-yuzde-25i-tamamliyor-953195/

Dianyu, Z. (2005). English learning strategies and autonomous learning. Foreign Language Education, 1, 012.

Dickinson, L. (1995). Autonomy and motivation a literature review. System, 23(2), 165174. https://doi.org/10.1016/0346-251X(95)00005-5

Ehrman, M. E., \& Oxford, R. L. (1995). Cognition plus: Correlates of language learning success. The modern language journal,79(1), 67-89. https://doi.org/10.1111/j.1540$\underline{4781.1995 . t b 05417 . x}$

Ehrman, M., \& Oxford, R. (1990). Adult language learning styles and strategies in an intensive training setting. The modern language journal, 74(3), 311-327. https://doi.org/10.1111/j.1540-4781.1990.tb01069.x 
El-Dip, M.A.B. (2004). Language learning strategies in Kuwait: Links to gender, language level, and culture in a hybrid context. Foreign Language Annals. 7(1) 85-95. https://doi.org/10.1111/j.1944-9720.2004.tb02176.x

Ergün, E. (2011). An investigation into the relationship between emotional intelligence skills and foreign language anxiety of students at a private university [Unpublished doctoral dissertation]. Middle East Technical University.

Erkuş, A. (2005). Bilimsel araştırma sarmalı. Seçkin Yayıncılık.

Ertekin, Z. S. (2006). A study on the correlation between the learning strategies of the 4th and 5th graders and those in the textbook [Unpublished doctoral dissertation]. Dokuz Eylül University Educational Sciences Institute.

Gardner, R. C. (1985). Social psychology and second language learning: The role of attitudes and motivation. Arnold.

Harmer, J. (1991). The practice of English language teaching. Longman.

Hong-Nam, K., \& Leavell, A. G. (2007). A comparative study of language learning strategy use in an EFL context: Monolingual Korean and bilingual Korean-Chinese university students. Asia Pacific Education Review, 8(1), 71-88. https://doi.org/10.1007/BF03025834

Horwitz, E. K. (1988). The beliefs about language learning of beginning university foreign language students. The Modern Language Journal, 72(3), 283-294. https://doi.org/10.1111/j.1540-4781.1988.tb04190.x

Horwitz, E. K., Horwitz, M. B., \& Cope, J. (1986). Foreign language classroom anxiety. The modern language journal, 70(2), 125-132. https://doi.org/10.1111/j.1540$\underline{4781.1986 . t b 05256 . x}$

Jenkins, J. (2009). English as a lingua franca: Interpretations and attitudes. World Englishes, 28(2), 200-207. https://doi.org/10.1111/j.1467-971X.2009.01582.x

Jimenez, E., Lockheed, M. E., \& Paqueo, V. (1991). The relative efficiency of private and public schools in developing countries. The World Bank Research Observer, 6(2), 205-218. http://dx.doi.org/10.1093/wbro/6.2.205

Karasar, N. (2014). Bilimsel Araştırma Yöntemi(26. Baskı). Nobel Yayıncılık. 
Kormos, J., \& Kiddle, T. (2013). The role of socio-economic factors in motivation to learn English as a foreign language: The case of Chile. System,41(2), 399-412. http://dx.doi.org/10.1016/j.system.2013.03.006

Kothari, C. R. (2004). Research methodology: Methods and techniques. New Age International.

Lestari, M., \& Wahyudin, A. Y. (2020). Language Learning Strategies of Undergraduate EFL Students. Journal of English Language Teaching and Learning, 1(1), 25-30. https://doi.org/10.33365/jeltl.v1i1.242

Lewis, M. Paul, Gary F. Simons, and Charles D. Fennig (eds.). (2016). Ethnologue: Languages of the World, Nineteenth edition. Dallas, Texas: SIL International. Online version: http://www.ethnologue.com.

Lin, C. H., Zhang, Y., \& Zheng, B. (2017). The roles of learning strategies and motivation in online language learning: A structural equation modeling analysis. Computers $\mathcal{E}$ Education, 113, 75-85. https:/psycnet.apa.org/doi/10.1016/j.compedu.2017.05.014

Liu, D., Ahn, G. S., Baek, K. S., \& Han, N. O. (2004). South Korean high school English teachers' code switching: Questions and challenges in the drive for maximal use of English in teaching. Tesol Quarterly, 605-638. https://doi.org/10.2307/3588282

Liyanage, I., \& Bartlett, B. (2013). Personality types and languages learning strategies: Chameleons changing colours. System, 41(3), 598-608. https://doi.org/10.1016/j.system.2013.07.011

Meniado, J. C. (2016). Metacognitive Reading Strategies, Motivation, and Reading Comprehension Performance of Saudi EFL Students. English Language Teaching, 9(3), 117-129. http://dx.doi.org/10.5539/elt.v9n3p117

Naiman, N., Frohlich, M., Stern, H., \& Todesco, A. (1978). The good language learner. Research in Education Series. Ontario Institute for Studies in Education.

Nakata, Y. (2010). Toward a framework for self-regulated language-learning. TESL Canada journal, 1-1. https://doi.org/10.18806/tesl.v27i2.1047

Nyikos, M. (1990). Sex-related differences in adult language learning: Socialization and memory factors. The Modern Language Journal, 74(3), 273-287. https://doi.org/10.2307/327624

O'malley, J. M., \& Chamot, A. U. (1990). Learning strategies in second language acquisition. Cambridge university press. 
O'Malley, J. M., Chamot, A. U., Stewner-Manzanares, G., Kupper, L., \& Russo, R. P. (1985). Learning strategies used by beginning and intermediate ESL students. Language learning, 35(1), 21-46. https://doi.org/10.1111/j.1467-1770.1985.tb01013.x

Oxford, R. (1990). Language learning strategies: What every teacher should know. Newbury House Publishers.

Oxford, R., \& Nyikos, M. (1989). Variables affecting choice of language learning strategies by university students. The modern language journal, 73(3), 291-300. https://doi.org/10.2307/327003

Özdemir, A., Aydın, N. ve Akar-Vural, R. (2009). Çevre eğitimi öz-yeterlik algısı üzerine bir ölçek geliştirme çalışması. Dokuz Eylül Üniversitesi Buca Ĕ̆itim Fakültesi Dergisi, 26, 1-8. https://dergipark.org.tr/tr/pub/deubefd/issue/25438/268408

Padem, S. (2012). Üniversite hazırlık sınıfı öğrencilerinin dil öğrenme stratejileri kullanımlarının çeşitli değgişkenlere göre incelenmesi [Yayımlanmamış yüksek lisans tezi] Düzce Üniversitesi Sosyal Bilimler Enstitüsü.

Park, G. P., \& Lee, H. W. (2006). The characteristics of effective English teachers as perceived by high school teachers and students in Korea. Asia Pacific Education Review, 7(2), 236-248. https://doi.org/10.1007/BF03031547

Pawlak, M. (2019). Investigating language learning strategies: Prospects, pitfalls and challenges. Language Teaching Research. https://doi.org/10.1177/1362168819876156

Phakiti, A. (2003). A closer look at gender and strategy use in L2 reading. Language learning, 53(4), 649-702. https://doi.org/10.1046/j.1467-9922.2003.00239.x

Pintrich, R. R. (2000). The role of goal orientation in self-regulated learning. In M. Boekaerts, P. R. Pintrich, M. Zeidner (Eds), Handbook of Self- Regulation (pp, 451-501). Academic Press.

Punch, K. F. (2013). Introduction to social research: Quantitative and qualitative approaches. Sage.

Rao, Z. (2016). Language learning strategies and English proficiency: interpretations from information-processing theory. The Language Learning Journal,44(1), 90-106. https://doi.org/10.1080/09571736.2012.733886

Razak, N. Z. A., Ismail, F., Aziz, A. A., \& Babikkoi, M. A. (2012). Assessing the use of English language learning strategies among secondary school students in 
Malaysia. Procedia-Social and Behavioral

Sciences, 66, 240-246. https://doi.org/10.1016/j.sbspro.2012.11.266

Reid, J. M. (1987). The learning style preferences of ESL students. TESOL quarterly, 21(1), 87-111. https://doi.org/10.2307/3586356

Rubin, J. (1975). What the "good language learner" can teach us. TESOL quarterly, 41-51. Seidlhofer, B. (2009). Common ground and different realities: World Englishes and English as a lingua franca. World Englishes, 28(2), 236-245. https://doi.org/10.1111/j.1467971X.2009.01592.x

Senemoğlu, N. (2010). Gelişim öğrenme ve öğretim kuramdan uygulamaya (18. Bask1). Pegem Akademi.

Stern, H. H. (1975). What can we learn from the good language learner? Canadian Modern language review, 31(4), 304-318. https://doi.org/10.3138/cmlr.31.4.304

Tabachnick, B. G., \& Fidell, L. S. (2013). Using multivariate statistics (Sixth edition).Pearson Education.

Tang, M., \& Tian, J. (2015). Associations between Chinese EFL graduate students' beliefs and language learning strategies. International Journal of Bilingual Education and Bilingualism, 18(2), 131-152. https://doi.org/10.1080/13670050.2014.882882

Taylor, S. K., \& Cutler, C. (2016). Introduction: Les classes d'accueil et d'immersion: stratégies, pratiques et croyances. Canadian Modern Language Review, 72(4), 405-422. https://utpjournals.press/doi/10.3138/cmlr.72.4.405

Turan, S. (2009). Probleme dayalı öğrenmeye ilişkin tutumlar, öğrenme becerileri ve başarı arasındaki ilişkiler [Yayımlanmamış doktora tezi] Hacettepe Üniversitesi Sosyal Bilimler Enstitüsü.

Vrugt, A. and Oort, F. J. (2010). Effective self-regulated learning of university students. In Jesús de la Fuente Arias Mourad Ali Eissa (Ed.). International Handbook on Applying Self-Regulated Learning in Different Settings, 319-340. Almeria, Spain.

Wenden, A. (1991). Learner strategies for learner autonomy: Planning and implementing learner training for language learners. Prentice-Hall.

Wharton, G. (2000). Language learning strategy use of bilingual foreign language learners in Singapore. Language learning, 50(2), 203-243. https://doi.org/10.1111/0023$\underline{8333.00117}$ 
Wong, M. S. L. (2011). Language Learning Strategy Use: A Study of Pre-Service Teachers in Malaysia. Online Submission. https://eric.ed.gov/?id=ED521415

Xiaodong, H. (2004). Problems in autonomous English learning research in China [J]. Foreign Language World, 4(1), 68-81.

Zhang, F., \& Yin, P. (2009). A Study of pronunciation problems of English learners in China. Asian social science, 5(6), 141. https://doi.org/10.5539/ass.v5n6p141

Zimmerman, B. J. (2002). Becoming a self-regulated learner: An overview.Theory into practice, 41(2), 64-70. https://doi.org/10.1207/s15430421tip4102 2

Zimmerman, B. J., \& Martinez-Pons, M. (1988). Construct validation of a strategy model of student self-regulated learning. Journal of Educational Psychology, 80(3), 284-290. https://psycnet.apa.org/doi/10.1037/0022-0663.80.3.284

Zoubir-Shaw, S., \& Oxford, R. L. (1995). Gender differences in language learning strategy use in university-level introductory French classes: A pilot study employing a strategy questionnaire. Faces in a crowd: Individual learners in multisection programs, 181213. 